\title{
An Empirical Analysis on How the Building Quality, Tourism Attraction and Tourism Public Service Influence the Satisfaction of Tourism Real Estate Consumption
}

\author{
Zhiyong Jiang ${ }^{1,2}$, Jun $\mathrm{Li}^{3}$, Dexiang $\mathrm{Mei}^{4}$ \\ ${ }^{1}$ School of Economics and Management, Southwest Jiaotong University, Chengdu, China \\ ${ }^{2}$ Xihua Honors College, Xihua University, Chengdu, China \\ ${ }^{3}$ School of Management, Xihua University, Chengdu, China \\ ${ }^{4}$ School of Finance, Chongqing Technology and Business University, Chongqing, China \\ Email: tmlbt1978@163.com, meidexiang1101@126.com
}

How to cite this paper: Jiang, Z.Y., Li, J. and Mei, D.X. (2018) An Empirical Analysis on How the Building Quality, Tourism Attraction and Tourism Public Service Influence the Satisfaction of Tourism Real Estate Consumption. American Journal of Industrial and Business Management, $\mathbf{8}$, 1806-1816.

https://doi.org/10.4236/ajibm.2018.88122

Received: June 27, 2018

Accepted: August 19, 2018

Published: August 22, 2018

Copyright $\odot 2018$ by authors and Scientific Research Publishing Inc. This work is licensed under the Creative Commons Attribution International License (CC BY 4.0).

http://creativecommons.org/licenses/by/4.0/

\begin{abstract}
This article provides an analysis of related factors on consumer satisfaction for the tourism real estate from the perspective of consumer behavior and psychological. In addition, by using structural equation model, this paper has carried on an empirical research on how three factors such as tourism real estate construction quality, the quality of tourist attractions and tourism public service quality influence on the consumers' satisfaction with tourism real estate. The conclusion shows that above three factors have significant positive influence on customer satisfaction, and among them, the tourist attraction quality has maximum impact, tourism public service second and tourism real estate construction quality the least. The conclusion of this paper will contribute to the development of tourism real estate in China.
\end{abstract}

\section{Keywords}

Tourism Real Estate, Structural Equation Model, Customer Satisfaction

\section{Introduction}

With the improvement of people's living standard, more and more consumers begin to attach importance to both material life and spiritual life. As a comprehensive embodiment of material consumption and spiritual consumption, the consumption for tourism real estate is welcomed by more and more consumers. But what are the factors that influence consumers' purchasing decisions on 
tourism real estate? Few literatures have studied this topic in spite of many scholars have studied the factors that influence tourist satisfaction on some tourist destinations.

The consumption behavior of tourism real estate can not only be regarded as the short-term migration behavior of tourists, but also can be regarded as the frequent repeated tourists. However, the reason why the consumers revisit or purchase a tourism real estate is not only because the tourism real estate has a living function, it must be some characteristics in the tourism real estate that attract the consumers. Monroe \& Krishnan (1985) [1] pointed out that the consumers perceived value or satisfaction on tourism real estate influenced their consumption intention. According to some relevant studies, this paper thinks that three factors such as tourism attractions, tourism resources of public services and tourism real estate construction will be the important factors influence the customer perceived value and customer satisfaction degree which will influence consumers' purchasing decisions on tourism real estate. Moreover, with structural equation method, this paper explored the above three factors how to influence the customer perceived value and customer satisfaction degree.

The rest of the article is as follows. The second part provided relevant literature reviews and pointed out the contribution and deficiency of existing literature. The third part put forward the study hypothesis and a conceptual model on the impact mechanism of tourism real estate consumption satisfaction. The forth part explored measurement of variables on tourist attractions resource, tourism public service, construction quality, consumer' perceived value and consumer satisfaction. Based on the forth part, the fifth part conduct the data analysis with SPSS19.0 and AMOS17.0 by using a survey data on a well-known tourist and leisure scenic spots in Sichuan province, in China. According with the results of data analysis, we can see the quantitative relation between each variable. The last part is the conclusion and advice.

\section{Literature Review}

There is a great deal of literature on the study of whether tourists go to a particular tourist destination, but few literature overall and quantitatively explored which factors influenced consumers' purchasing decision on the tourism real estate. For example, Zheng et al. (2005) explored the residential location preference of residents in five metropolises such as Beijing, Shanghai, Guangzhou, Wuhan and Chongqing in China and found the environment, the urban scale and the rural infrastructure will affect the consumers' willingness to pay of travel and residence. Niu and Wang (2015) [2] in the study of high-speed rail how to impact on the tourists' choice for travel destination, thought that after the high-speed railway opened, the density of tourist traffic network, tourist resources endowment and tourism service reception ability become the important factors. Liu and Wang (2015) [3] explored the satisfaction degree of the foreign visitors to China for the urban tourism public service in China. They draw a 
conclusion that in all the tourism services, the tourist reception service, the convenient transportation service, the public information service, the security service and the recreational facilities were the direct five factors affecting the consumer satisfaction degree. Zhang and Hong (2012) [4] thought the landscape and environment in the tourist destination were the leading factors that influenced the experience sense of tourists. Chen (2012) [5] found in Hainan Island in China, the reception service, environment and resources value have significant positive influence to revisit intention of visitors. Xu (2014), Guan (2015) and Pan (2014) [6] [7] [8] thought that the tourism public service system is the key factor that affects tourists' satisfaction. In line with above research results, we find that these important factors such as tourist resources endowment, tourism public service system, the tourist reception service, the convenient transportation service etc. will greatly influence the consumers' decision on visiting a tourist destination. But will these factors also affect consumers' purchases of tourist real estate?

Generally, whether a consumer will buy a tourist real estate greatly depends on the consumer' perceived value and satisfaction on the real estate. Monroe \& Krishnan (1985) [1] pointed out that there was a relationship between perceived value and spending willingness. Cronin \& Brady (2000) [9] confirmed that the consumer perceived value directly affected the consumer behavior. Some scholars also have discussed some factors influencing tourism real estate consumption from different views. Zhang (2013), Luo (2013) [10] [11] and He (2014) [12] thought the tourism attraction resource is an important basis for tourism real estate. Dong (2009) [13] showed that residential building quality and public products jointly constituted the consumers' perceived value, and customers' perceived value significantly affects customer satisfaction.

According to the related research results, the values which tourism real estate can bring to the consumers come from not only the tourism real estate, but also including architectural features by relying on the resources of tourist attractions and the surrounding tourism public service. The consumers' perceiving value on tourism real estate not only includes the construction quality of tourism real estate, but also the surrounding tourism resources, basic supporting products and related tourism services etc.

Existed literatures partly explored the topic that which factors would influence the tourism real estate consumption, but these literatures were short of systematic and quantitative result. Therefore, the paper will try to more comprehensively investigate the topic that which factors would and how to influence the tourism real estate consumption. Because the tourism real estate development greatly depends on the cooperation between the government and enterprises, the conclusion of this paper will contribute to the development of tourism real estate in China.

\section{Study Hypothesis and the Conceptual Model}

According to the related research results, this paper will divided the factors in- 
fluencing tourism real estate consumption into three categories such as the construction quality of tourism real estate, tourist attraction resource and tourism public service.

\subsection{Introduced Variables}

\subsubsection{The Construction Quality of Tourism Real Estate}

The construction quality of tourism real estate is the main body of its direct value perception. The construction quality includes not only the architectural style and interior structure of the house but also the position and orientation, community facilities and environment, the developer brand and the property management level. Consumers have different preferences for different architectures. For example, some consumers perhaps like the pseudo-classic architecture and the others like modern architecture. Some consumers perhaps like the Chinese style and the others like the European architecture. Meanwhile, the interior structure of the house will greatly influence consumers' perception value such as the orientation of house, the area of each room and balconies etc. Furthermore, the property management level, community facilities and surrounding environment are the importance factors influence consumer' value perception.

\subsubsection{Tourist Attraction Resource}

According to Xu et al. (2014), the tourism attraction resource is actually a combination concept, which is a combination of tourism resource and tourism attraction. They are both used to refer to tourist objects that are attractive to tourists and most of them belong to public resources. But tourist attractions has more use value, it can also refer to the scenic area, scenic spots, theme park, some festival activities, tourism resources and tourist attractions. Zhu et al. (2006) pointed out that tourism real estate is a tourism product and property form with the function of tourism, leisure and vacation. Zhang et al. (2013) thought tourism real estate mainly refers to the real estate or land form represented by natural ecological scenic spots such as nature reserves, scenic spots, forest parks and geological parks. As a result, tourism attraction resource is an important content of tourism real estate development.

As far as tourists are concerned, the core attraction resources of tourism have an important influence on tourists' satisfaction. Luo (2013) and He (2014) took a research on the relationship between the urban characteristics and urban tourist satisfaction and draw a conclusion that attraction resources in tourism resources had significant positive influence on the tourist satisfaction. Previous studies have shown that tourist attractions are an important factor influencing tourists' satisfaction. So does tourism attractions have an impact on consumer satisfaction of tourism real estate? A study of this problem is of great significance for us to correctly understand the role of tourist attractions in tourism real estate consumption.

\subsubsection{Tourism Public Service}

The main content of tourism public service includes three aspects such as the 
tourism infrastructure, destination marketing and tourist's rights and interests and it is a public welfare services. The tourism public service system is the key factors influencing the tourist satisfaction and destination competitiveness. Xu et al. (2014), Guan et al. (2015) and Chen et al. (2016) thought that the quality of tourism public service positively affected the overall satisfaction of tourists, the trust of tourists to the government and the image of tourist destinations. Tourism public service affects tourists' satisfaction, so does it have an impact on consumers' satisfaction on tourism real estate? The research on relations between tourism public service and consumer satisfaction of tourism real estate will help us to correctly view the role of government in tourism real estate consumption.

\subsection{The Logical Relationship between Variables and the Proposed Research Hypotheses}

The consumer satisfaction degree on tourism real estate comes from the perceived value for tourism real estate which is the basis factor influencing consumers purchase decision for tourism real estate.

The tourism real estate architecture is the main body of its direct value perception. Due to the function of tourism real estate, consumer perception on tourism real estate is depended on not only the living value of tourism real estate but also the tourist attractions around tourism real estate. In addition, tourism public services around tourism real estate still have an important influence on the realization and improvement on core functions of tourism real estate. Tourist attractions and public services on tourism resources provide the "non-use value" beyond "use value". The "non-use value" has become an important part of consumer perceived value, which exert a direct impact on consumer behavior and consumer satisfaction.

In addition, consumers will choose to purchase tourism real estate in places with abundant tourism resources and perfect tourism public service. The tourism real estate construction, the tourist attractions and tourism public service is not independent, and there is some correlation among them. The high quality of tourist attractions needs an accordingly high quality tourism public service. At the same time, in the regions with high tourism public service quality, the quality of the tourist attractions can be relatively higher. In terms of tourism real estate, when the surrounding tourism resources and tourism public service quality high, needs a high quality to adapt themselves to the tourism real estate. On the other hand, the tourist attractions and tourism public service with high quality will improve the quality of the tourism real estate. Therefore, there are synergistic correlations among them.

Based on the above discussion, the following hypotheses are proposed:

Hypothesis 1: The construction quality of tourism real estate has a significant positive influence on the perceived value of consumers.

Hypothesis 2: The quality of tourist attractions has a significant positive impact on the perceived value of consumers.

Hypothesis 3: Tourism public service quality has a significant positive impact 
on perceived value of consumers.

Hypothesis 4: The construction quality of tourism real estate has a significant positive influence on the consumer satisfaction on tourism real estate.

Hypothesis 5: The quality of tourism attracting has a significant positive effect on the satisfaction of tourism real estate consumers.

Hypothesis 6: The quality of tourism public service has a significant positive effect on the consumer satisfaction of tourism real estate.

Hypothesis 7: The perceived value of tourism real estate consumers has a significant positive impact on consumer satisfaction.

Hypothesis 8: The building quality of tourism real estate, tourist attraction quality and public service quality of tourism are codependent.

\subsection{Conceptual Model}

According to the logical relationship between the selected variables, the above hypotheses and on the basis of existing research results, we determined the following concept model, see Figure 1.

\section{Measurement of Variables}

The previous section illustrates the logical relationship between five variables. Next, this paper will show how to measure these five variables.

\subsection{Measurement Dimensions on Tourist Attractions Resource and Tourism Public Service}

Some related researches explored how to measure the tourist attractions resource and tourism public service. Shen et al. (2013) built an evaluation model of ecological tourism resource with 36 major eco-tourism areas in Jiangsu province in China as a sample and thought ecotourism resources conditions, regional conditions and the development potential were able to represent the tourist attractions resource. Yan et al. (2013) thought the tourism resources abundance and

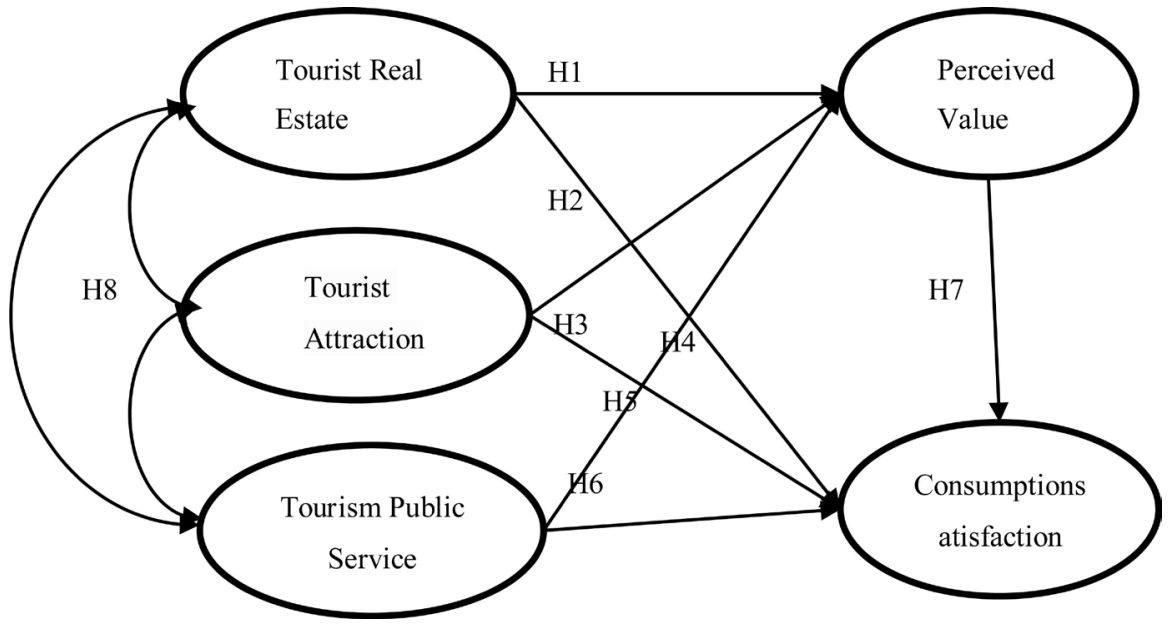

Figure 1. The conceptual model of the impact mechanism of tourism real estate consumption satisfaction. 
the tourism resources taste were able to represent the tourist attractions resource. Jing et al. (2017) discussed the spatial structure of tourist resources attraction in Chengdu in China and thought that resource quality, resource recreation value and resource abundance were able to represent the tourist attractions resource. Combine some research results, this paper chooses five dimensions to measure the quality of tourist attractions. The five dimensions are leisure value, attractions, reputation, experience value and the ecological environment, respectively.

For tourism public service, some scholars recently had also proposed some measure dimensions. Liu et al. (2015) thought five factors were able to represent tourism public service such as tourist reception service, convenient transportation service, public information service, safety guarantee service and convenient recreation service. He et al. (2017) thought four factors were able to represent tourism public service such as information services, security services, communications services and transportation services in the tourist destination. Rong et al. (2015) thought eight factors were able to represent tourism public service such as tourism public security, environmental management, tourism public transportation facilities, public recreational facilities, tourism public information, travel insurance, convenience service and travel network information platform.

Based on the convenient and the recent research results, this paper selects five indicators to reflect the quality of tourism public service. They are tourism information service, tourism security guarantee measures, tourism transportation service, infrastructures and tourism convenience service, respectively.

\subsection{Measurement Index on Construction Quality, Consumer Perceived Value and Consumer Satisfaction}

According to the interview result, combined with related literature on residential construction quality, this paper selected six indexes including building area, construction quality and structure, the position and orientation, community facilities and environment, developers brand and property management level to reflect the construction quality of tourism real estate.

Based on Dong (2009) [13] and combined with the characteristics of tourism real estate, three options whether the consumers think their own tourism real estate are attractive, value for money and worth buying or not can be used for reflecting the tourism real estate value perception.

Based on Rosenberg (1974) [14], the measurement of consumption satisfaction on tourist real estate is reflected by the satisfaction of the environment, the satisfaction of service, the satisfaction of life and the satisfaction of functional quality.

\section{Survey Subject and Data Analysis}

\subsection{Survey Subject}

The concerned area in this paper is the well-known tourist and leisure scenic spots in Sichuan province, in China. The research object is the people who have purchased tourism real estate and live on their own. 
The development of the scale is divided into several steps. Firstly, according to the related literature, we make a preliminary scale. Secondly, A small scale interview was conducted for some tourism real estate buyers. The questions in the preliminary scale were analyzed and corrected according to the interview results. Thirdly, we find some professionals engaged in tourism real estate development and sales to communicate with us and after consulting their views, we further revise the scale. Finally, before the formal questionnaire was issued, we tested the scale on the reliability and validity. Likert 5-level scale was adopted to design the scale. A total of 500 questionnaires were issued and 447 valid questionnaires were recovered, with an effective rate of $89.4 \%$ and a sampling period of 3 months. SPSS19.0 and AMOS17.0 were used to analyze the data in this study.

\subsection{Data Analysis}

\section{1) Reliability and validity tests}

The Alpha value of the total samples is all greater than 0.80 , indicating the high consistent and good reliability. As seen in the Table 1, the KMO value of the spherical test of the scale is 0.950 , Bartlett value is significant (see Table 1), and the percentage of variance of cumulative interpretation is over $70 \%$. As a result, the scale has good reliability and validity.

\section{2) Model fitting}

As seen in the Table 2, the model was fitted well.

Table 1. KMO and Bartlett tests.

\begin{tabular}{lcc}
\hline \multicolumn{2}{c}{ Kaiser-Meyer-Olkin } & 0.950 \\
\hline \multirow{3}{*}{ Bartlett tests } & The approximate chi-square & 6831.393 \\
& df & 253 \\
& Sig. & 0.000 \\
\hline
\end{tabular}

Note: The results were from Spss19.0.

Table 2. Model index fitting.

\begin{tabular}{|c|c|c|c|c|}
\hline \multirow{2}{*}{ Index } & \multicolumn{2}{|c|}{ Reference boundary value } & \multirow{2}{*}{ Actual value } & \multirow{2}{*}{ Fitting result } \\
\hline & Acceptable & Better fitting & & \\
\hline $\mathrm{x}^{2} / \mathrm{df}$ & $<3$ & I & 1.673 & Better \\
\hline RMSEA & $<0.1$ & $<0.05$ & 0.039 & Better \\
\hline SRMR & $<0.08$ & I & 0.035 & Better \\
\hline GFI & $>0.8$ & $>0.9$ & 0.934 & Better \\
\hline AGFI & $>0.8$ & $>0.9$ & 0.918 & Better \\
\hline NFI & $>0.9$ & I & 0.947 & Better \\
\hline TLI & $>0.9$ & $>0.95$ & 0.975 & Better \\
\hline CFI & $>0.9$ & / & 0.978 & Better \\
\hline
\end{tabular}

Note: The results were got according to the analysis results with softwareSPSS19.0 and AMOS17.0. 
Correlation analysis between tourism real estate construction, tourism attractions, tourism public service and consumer perceived value and consumer satisfaction are shown in the Figure 2.

Figure 2 shows that at the significance level of 0.01 , the correlation coefficient between architectural quality and perceived value of tourism real estate is 0.22 , the correlation coefficient between tourist attraction quality and perceived value is 0.34 , and the correlation coefficient between tourism public service quality and perceived value is 0.27 , which shows a significant positive correlation. Meanwhile, at the significance level of 0.01 , the correlation coefficient between building quality and consumer satisfaction of tourism real estate is 0.16 , and the correlation coefficient between tourism public service quality and consumer satisfaction is 0.25 . At a significant level of 0.05 , the correlation coefficient between tourist attraction quality and consumer satisfaction was 0.12 , showing a significant positive correlation. At the significance level of 0.01 , the correlation coefficient between perceived value and consumer satisfaction is 0.48 , showing a significant positive correlation. At 0.01 significant level, the tourism real estate construction quality and the tourist attractions in the correlation coefficient is 0.47 , the quality of tourist attractions and tourism public service quality of the correlation coefficient is 0.71 , tourism real estate construction quality and the quality of public service of the correlation coefficient is 0.52 , which were all significantly positive correlation.

\section{3) Empirical results and explanations}

From the above result, we know the all eight hypothesis from $\mathrm{H} 1$ to $\mathrm{H} 8$ pass the test. There is a positive correlation between each other, but the value of correlation coefficient is certain different. As far as perceived value is concerned, the coefficient of tourist attractions is the largest, the coefficient of tourist public services is the second highest, and the coefficient of tourist real estate buildings is the smallest.

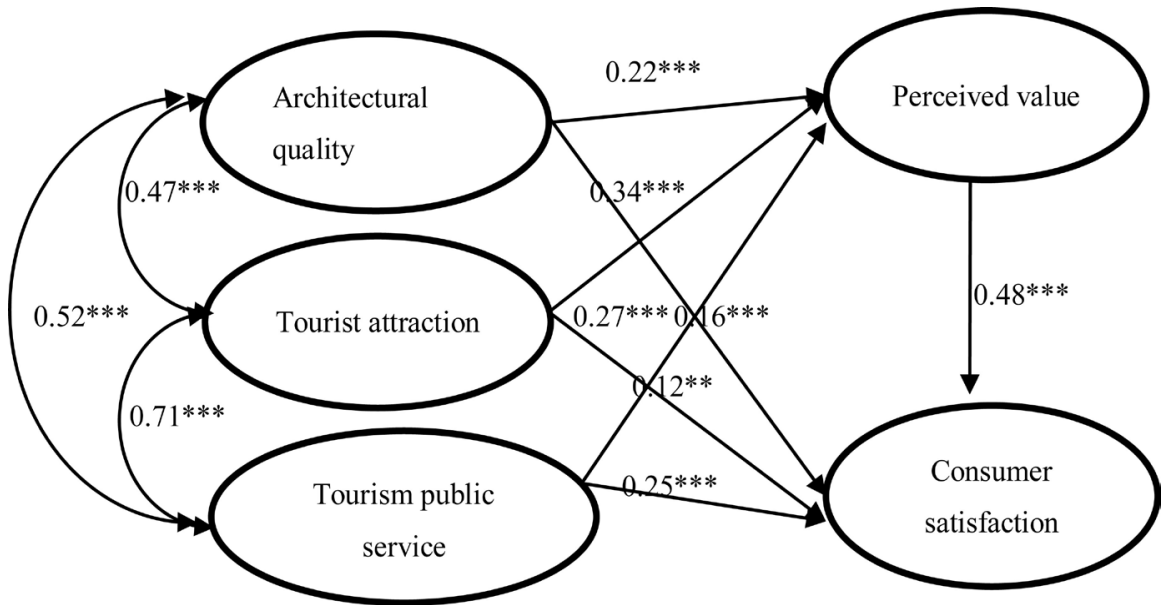

Note: ${ }^{\star *}$ means significant at $5 \%$ and ${ }^{\star \star}$ means significant at $1 \%$ and the result are from AMOS17.0.

Figure 2. The statistical results of the influencing mechanism model on tourist real estate consumer satisfaction. 


\section{Conclusions and Advice}

The empirical results showed that the three factors such as tourism real estate construction, tourism attractions, and tourism resources of public services had different effects on customer perception of value and consumer satisfaction.

Consumer perceptive value will affect consumer purchase decision. In accordance with the different impacts of above three factors on the tourism real estate perceived value, we can find that the consumers prefer to purchase tourism real estate in the region with rich tourism resources, famous scenic spot, strong tourist attraction, high ornamental value and experience, comfortable climate and air. In addition, buyers attach importance to tourism public service. The buyers hope that around the purchased tourism real estate, the surrounding tourism transportation is convenient, the infrastructure is perfect, at the same time, the tourism information is sufficient and convenient. Moreover, it is hoped that the area, structure, quality, location, orientation, property service, community greening and facilities of tourism real estate can meet consumer' diversified needs.

As a result, the tourism management department should strengthen the supervision of tourism real estate development enterprises and the tourism development of tourism real estate should focus on how to coordinate the quality, the tourism resources and tourism public service. The tourism real estate development companies should take the tourist real estate building area, construction quality, the structure and function, property management services, community greening and facilities into consideration when improving the quality of tourism real estate construction and community.

Of course, despite this article provides an analysis of related factors on consumer satisfaction for the tourism real estate from the perspective of consumer behavior and conducted an empirical analysis with structural equation method, there are some shortcomings in this paper. Firstly, there are some characteristic differences in tourist real estate in different tourist regions, so the result with the sample in this paper is not necessarily general. Secondly, for convenience, the selected indicators on variables are some subjective and not necessarily comprehensive, which maybe lead to an arbitrary conclusions. To get a more accurate conclusion, we need more regional data for empirical analysis.

\section{Conflicts of Interest}

The authors declare no conflicts of interest regarding the publication of this paper.

\section{References}

[1] Monroe, K.B. and Krishnan, R. (1983) A Procedure for Integrating Outcomes Across Studies. Association for Consumer Research, 10, 503-508.

[2] Liu, C.X. and Wang, D.G. (2015) Evaluation of the Satisfaction of Foreign Tourists on the Public Service System of Urban Tourism in China-Taking Suzhou as an Example. Urban Development Research, 07, 101-110. 
[3] Zhu, Y. and Huang, Z.F. (2006) Research on Real Estate Development Model in Tourist Areas. Anhui Agricultural Science, 21, 16-18.

[4] Zhang, H.M., Hong, J. and Zhang, W.J. (2012) Hierarchical Relationship Model of Perceived Value of Tourist Destination Tourists. Human Geography, 04, 125-130.

[5] Chen, H.B. (2012) The Perception Difference of Tourist Attraction and Its Influence on Revisiting Intention-Taking Hainan International Tourism Island as an Example. Journal of Beijing No.2 Foreign Languages Institute, 09, 73-78.

[6] Xu, C.R. (2007) Research on Basic Problems of Tourism Real Estate. Science and Technology Information, 12, 236-238.

[7] Guan, X.H., Li, J.Y. and Xie, L.S. (2015) Influence of Tourism Public Service Quality on Tourism Destination Image. Tourism Science, 05, 27-38.

[8] Pan, Y.R. and Xu, J.F (2014) Theory Cognition and Practice on Tourism Public Service. Tourism Tribune, 01, 28-37.

[9] Zhang, J.S. (2013) Definition and System Construction of Tourism Real Estate. Journal of Beijing Second Foreign Language Institute, No. 03, 13-20.

[10] Luo, W.B. and Xu, F.X. (2013) Influence of Urban Characteristics on The Satisfaction of Urban Tourists-Quantitative Analysis Based on the Probit Model. Tourism Journal, 11, 50-58.

[11] He, Q.F. (2014) Research on the Influence Factors of Tourists Satisfaction in Cultural Heritage Scenic Spot Based on Grounded Theory-A Case Study of Tourists Comments in Beijing 5A Scenic Spot of Dianping.com. Economic Geography, 01, 168-174.

[12] Cronin and Brady (2000) A Model of Perceived Value for Leisure Travel Products. Urban Development Research, 09, 10-16.

[13] Dong, X.S. (2009) Research on Real Estate Development Model in Tourist Areas. Anhui Agricultural Science, 21, 16-18.

[14] Rosenberg (1974) Consumer Reporting: A Conceptual Framework for the Organizational Level. Journal of Consumer Policy, 08, 267-285. 